\title{
Source and depositional processes of coarse-grained limestone event beds in Frasnian slope deposits (Kostomłoty-Mogiłki quarry, Holy Cross Mountains, Poland)
}

\author{
Aleksandra Vierek \\ University of Silesia, Faculty of Earth Sciences, Będzińska 60, 41-200 Sosnowiec, Poland; \\ e-mail: aleksandra.vierek@us.edu.pl
}

\begin{abstract}
The Kostomłoty-Mogiłki succession is situated in the Kostomłoty transitional zone between the shallow-water Kielce stromatoporoid-coral platform and the deeper Łysogóry basin. In the Kostomłoty-Mogiłki quarry, the upper part of the Szydłówek Beds and Kostomłoty Beds are exposed. The Middle-Upper Frasnian Kostomłoty Beds are composed of shales, micritic and nodular limestones with abundant intercalations of detrital limestones. The dark shales and the micritic and nodular limestones record background sedimentation. The interbedded laminated and detrital limestones reflect high-energy deposition (= event beds). These event beds comprise laminated calcisiltites, fine-grained calcarenites, coarse-grained grain-supported calcirudites fabrics, and matrix-supported calcirudites. The material of these event beds was supplied by both erosion of the carbonate-platform margin and cannibalistic erosion of penecontemporaneous detrital limestones building the slope of this platform. Storms and the tectonic activity were likely the main causes of erosion. Combined and gravity flows were the transporting mechanisms involved in the reworking and redeposition.
\end{abstract}

Keywords: limestones, carbonate-platform slope, event beds, Upper Devonian, Holy Cross Mountains

\section{Introduction}

The palaeogeographical pattern of the Givetian to Frasnian in the Holy Cross Mountains (HCM) in Poland (Fig. 1) is characterized by two distinct tectonic regions (Szulczewski, 1971, 1977): the northern palaeolow in the Łysogóry region and the southern palaeohigh in the Kielce region. Later research (Racki, 1993; Racki \& Bultynck, 1993) identified a separate Kostomłoty transitional zone between the shallow-water Kielce stromatoporoid-coral platform and the broadly-defined Łysogóry basin deposits.
The Lower Devonian is represented by a complex terrigenous succession with a continental and shallow-marine facies (Szulczewski, 1977, 1995). At the transition from the Early to the Middle Devonian, a marine transgression resulted in a decrease in siliciclastic sedimentation and in a variety of marine environments in the area now covered by the HCM. In the Kielce region, the biostrome-colonized platform, characterizing the Givetian, evolved into a stromatoporoid-coral reef-rimmed platform complex (the Dyminy reef of Narkiewicz, 1988, or the Dyminy reef complex of Racki, 1993) as a result of the Early and Middle Frasnian IIb/c and IIc transgressions (global cycles of John- 


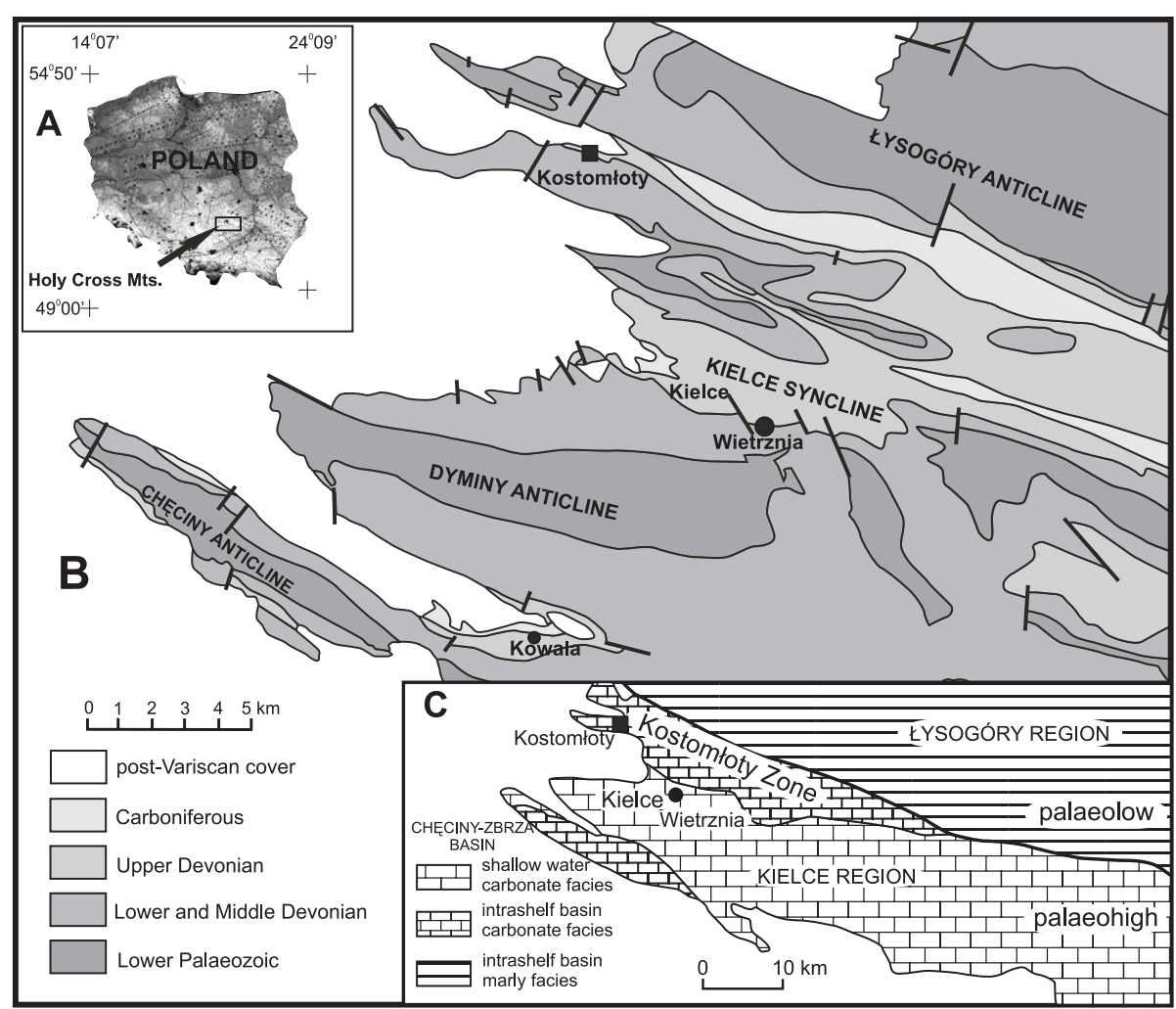

Fig. 1. Geographical, geological and palaeogeographical setting.

A - Location of the Holy Cross Mts. in Poland; B - Geological sketch map of the western part of the Holy Cross Mts. (after Szulczewski, 1971); C - Palaeogeographical pattern of the Givetian to Frasnian in the Holy Cross Mts. (after Racki, 1993) with the location of the Kostomłoty site.

son et al., 1985; Racki, 1993). The Dyminy reef developed over the northern marginal zone of the extensive Kielce carbonate platform. The reef was surrounded by intra-shelf basins: the Checciny-Zbrza Basin to the South and the Łysogóry-Kostomłoty Basin to the North (Szulczewski, 1995). The northern basinal area in the Givetian and Lower Frasnian consists of darkcoloured marls and marly limestones defined as the Szydłówek Beds (= basinal facies of Szulczewski, 1971). These Szydłówek Beds reflect rhythmic, quiet hemipelagic deposition in the oxygen-depleted basin of the Kostomłoty transitional zone, sporadically affected by bioclastic debris derived mainly from the evolving Kielce carbonate platform (Racki \& Bultynck, 1993). They underlie Middle to Upper Frasnian coarse-grained limestones and build a succession of slope deposits (= the Kostomłoty Beds), which reflect high-energy deposition. In the Upper Devonian, the northern ŁysogóryKostomłoty Basin received material that became reworked from the Dyminy reef in the
Kielce region and the carbonate shelf stretching out North-West of the Łysogóry facies (Szulczewski, 1968, 1971, 1995).

\section{The study area}

The village of Kostomłoty lies a few kilometres NNW of Kielce in the NW part of the HCM (Fig. 1). The small, abandoned KostomłotyMogiłki quarry is situated on the eastern side of the Kostomłoty Hill, one of the hills where the Devonian carbonates are well exposed. The quarry is situated in the southern flank of the Miedziana Góra syncline whereas the Kostomłoty Hills show Frasnian outcrops of the axial part of the syncline. South of these hills, Givetian dolomites are exposed, while an unconformity representing the boundary between the Frasnian and the Zechstein occurs in the North (Szulczewski, 1981).

In the Kostomłoty-Mogiłki quarry, the upper part of the Szydłówek Beds and the Kostomłoty 
Beds are well exposed; they are partly strongly tectonically deformed. The Szydłówek Beds comprise the Lower Frasnian (the transitans Zone with Ancyrodella africana and A. pramosica: Racki et al., 2004). The Kostomłoty Beds range from the Middle Frasnian punctata Zone with A. gigas to the hassi s.l. Zone with A. curvata (fig. 10 in Pisarzowska et al., 2006) to the ?Upper Frasnian Early rhenana Zone (= gigas Zone of Szulczewski, 1971; see Ziegler \& Sandberg, 1990). The hemipelagic Szydłówek Beds are characterized by intercalations of dark-coloured marly shales, marls and nodular marly limestones. These beds contain brachiopods, tabulate corals, crinoid detritus and styliolinids (Pisarzowska et al., 2006).

The disappearance of marly shales and limestone intercalations and the gradual introduction of fine-grained and laminated limestones and conglomerates mark the transition from the Szydłówek Beds to the overlying Kostomłoty Beds. The first thick (approx. $0.5 \mathrm{~m}$ : Racki et al., 1985; Racki \& Bultynck, 1993) conglomerate layer defines the base of the Kostomłoty Beds. Szulczewski (1981) subdivided the Kostomłoty Beds into six lithological units (A-F): (A) calcarenites intercalated by marly limestones; (B) breccias intercalated by calcarenites; (C) breccias; (D) calcarenites with crinoidal limestones; (E) calcarenites with black cherts; and (F) calcirudites with conglomerates at the top. Units $\mathrm{E}$ and $\mathrm{F}$ are absent in the Kostomłoty-Mogiłki quarry. According to Pisarzowska et al. (2006), the lower part of the Kostomłoty Beds comprises fossil-poor lime mudstones and marly limestones with a few layers with intraclasts, and shaly intercalations; it shows wavy and nodular bedding with intercalations of conglomerates.

According to Szulczewski $(1968,1971,1981)$, the nodular and micritic limestones with marly shales represent autochthonous basin deposits, whereas the calcarenites and calcirudites, including the breccias and conglomerates, represent allochthonous sediments transported by slumping and turbidity currents. In later years, Kaźmierczak \& Goldring (1978), Szulczewski et al. (1996), Racki \& Narkiewicz (2000) and Vierek $(2007 a, b)$ suggested the possible influence of storm events or even tsunamis on the depo- sition of the Upper Devonian coarse-grained limestones. Alternative interpretations of the depositional mechanism of the coarse-grained limestones are, however, worth to be discussed. The present contribution details a new sedimentological analysis of the Kostomłoty Beds in the Kostomłoty-Mogiłki quarry, carried out in order evaluate the earlier interpretations of the reworking and transport mechanisms of the coarse-grained limestones.

\section{Methods}

A succession of about $100 \mathrm{~m}$ thick of the Kostomłoty Beds is exposed in the KostomłotyMogiłki quarry (Fig. 2). Three sections were examined bed-by-bed with particular attention for their sedimentary structures. Section I is approx. $15 \mathrm{~m}$ thick; it was designated earlier by Racki et al. (2004) and Pisarzowska et al. (2006) as Mogiłki Kt-V. Section II, which is approx. 17 $\mathrm{m}$ thick has not been investigated earlier, nor has been Section III, which is somewhat more than $24 \mathrm{~m}$ thick. Several facies were distinguished on the basis of field observations. Additionally, 46 thin sections of approx. $2.5 \times 5.5$ $\mathrm{cm}$ each and 24 thin sections of approx. $5.5 \times 8.0$ $\mathrm{cm}$ each were examined under a microscope. The limestone classification and nomenclature follows Folk $(1959,1962)$.

\section{Results}

The lower part of Section I consists of dark marly shales with intercalations $(2-38 \mathrm{~cm}$ thick of marly and micritic limestone); this part belongs to the Szydłówek Beds (Figs. 2A-B and 3 ). Towards the top of the section, the thicknesses of the shales and marly limestones decrease, and limestones with lamination and/or a few micritic clasts appear. The quantity and thickness of laminated limestones progressively increases. The base of the Kostomłoty Beds is defined by the first thick (approx. $29 \mathrm{~cm}$ ) coarse-grained layer (layer 66: flat-pebble conglomerate; Figs. 2C and 3). Above this layer, the number of laminated micritic limestones, calcarenites and calcirudites distinctly increases. 


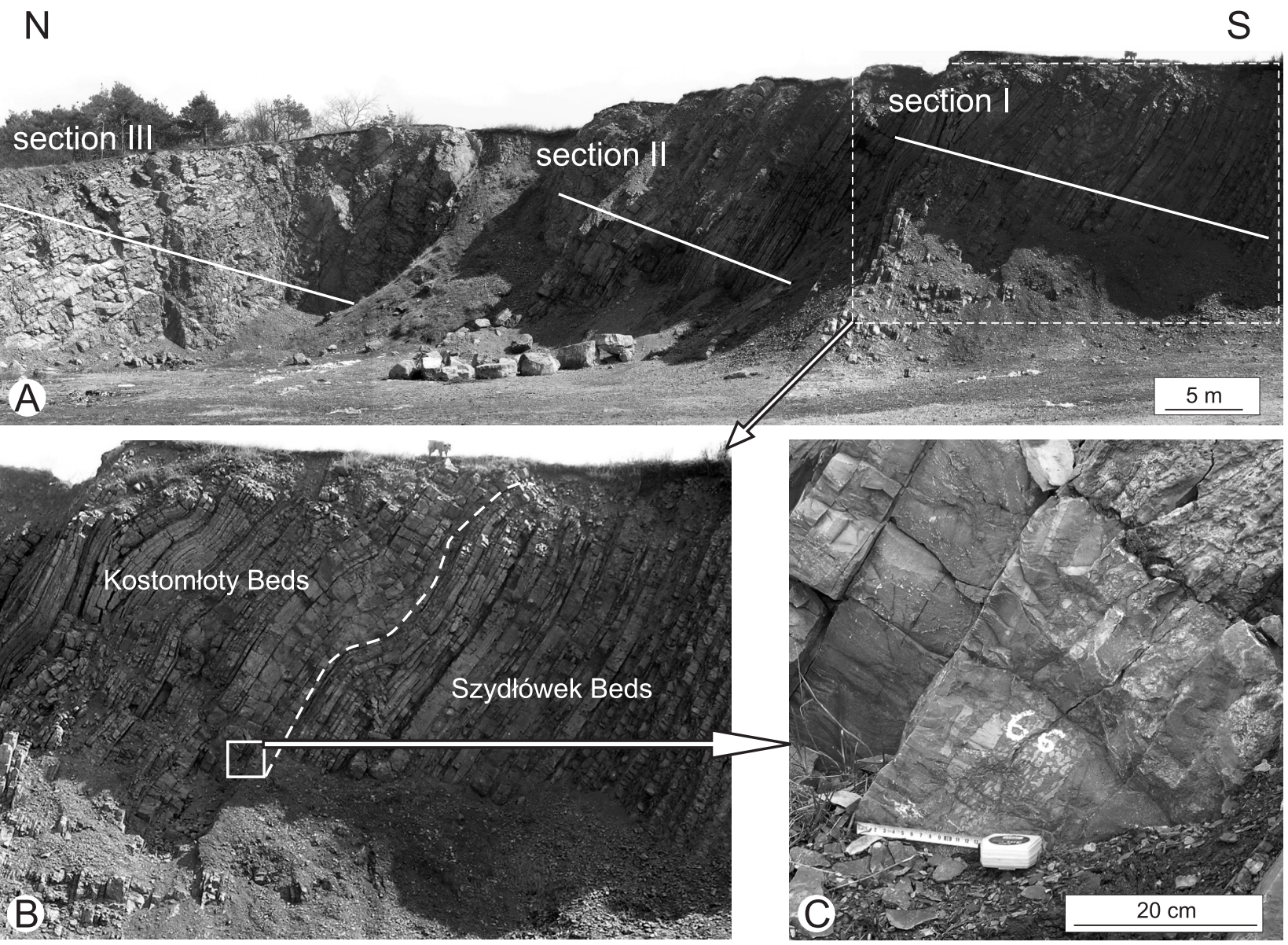

Fig. 2. The Kostomłoty-Mogiłki quarry.

A - Field positions of the three measured sections; B - Section I: boundary between the Szydłówek and Kostomłoty Beds; C - Close-up of a flat-pebble conglomerate in the basal part of the Kostomłoty Beds.

Nevertheless, the base of the Kostomłoty Beds is dominated by wavy to nodular limestones (Fig. 3) (Section I, layers 73-108). Above layer 130, the intercalations of coarse-grained layers are frequent, but they are still thin- to mediumbedded. Only in the lower part of Section II do thick breccias and conglomerates appear. The entire Section II and the lower and middle parts of Section III are built mostly of thickbedded calcirudites, including breccias and conglomerates. Only in the uppermost part of Section III do calcirudites vanish and micritic and laminated limestones reappear (Fig. 3).

The laminated and detrital limestones reflect high-energy deposits (they are interpreted as event beds in the sense of Flügel, 2004, p. 597). They contain three lithofacies, distinguished on the basis of grain size, composition, texture and sedimentary structures. The facies are: laminated calcisiltites (F1), fine-grained calcarenites (F2), and coarse-grained calcirudites (F3); lithofacies F3 can be subdivided into grain-supported calcirudites (F3A) and matrixsupported calcirudites (F3B).

The thicknesses and lithological characteristics of the event beds vary per section. The thicknesses of the coarse-grained beds and their proportion increase upwards (Section I: $29 \%$ of detrital limestones; Section II: $81 \%$ of detrital limestones; Section III: $85 \%$ of detrial limestones). This implies that the proportion and thicknesses of the marly and wavy-bedded to nodular limestones decrease. The base of the Kostomłoty Beds shows no bioturbation, but the micritic- and laminated sediment is slightly bioturbated in the middle and upper

Fig. 3. Lithological sections from the Kostomłoty-Mogiłki quarry. Conodont zonation of Section I according to Pisarzowska et al. (2006). 
$\int$ bioturbation

$>$ amalgamation

$\Delta$ normal grading

$\nabla$ inverse grading

$\sim$ hummocky cross-stratification

calcisiltites (F1)

marly shales

28- nodular limestone

00 calcirudites (breccia - F3A)

: calcirudites (flat-pebble conglomerate - F3B)

calcarenites (F2)

Ea wavy lamination

堅采 planar lamination

F1, F2, F3A, F3B - lithofacies (see text)

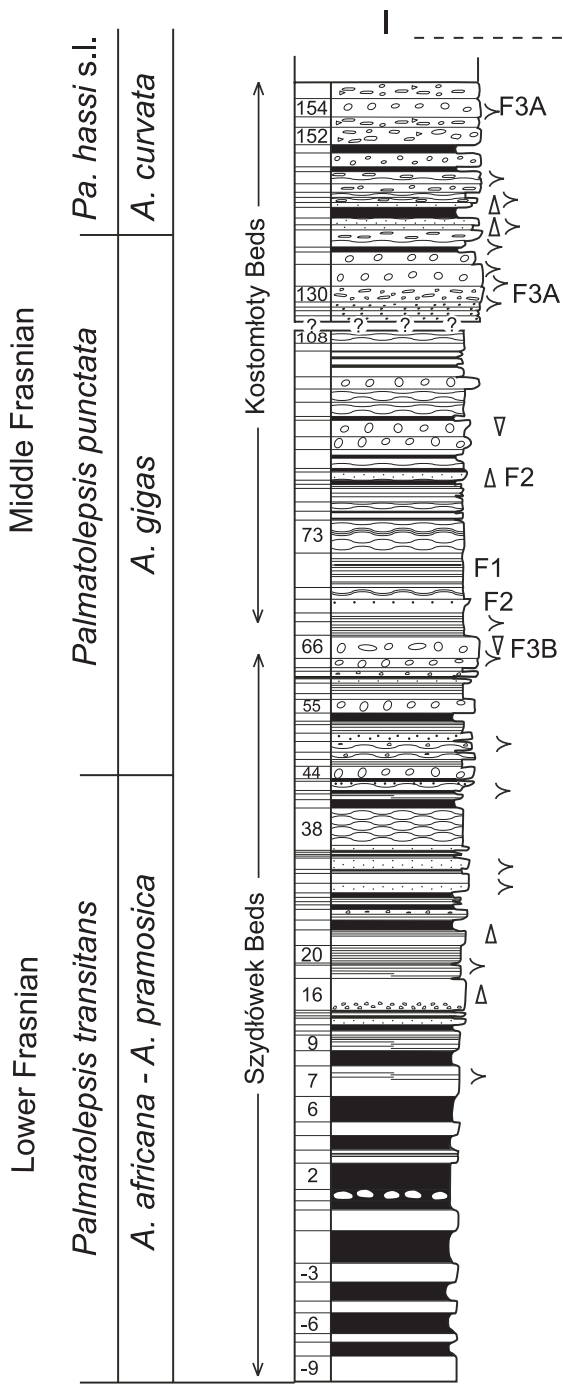

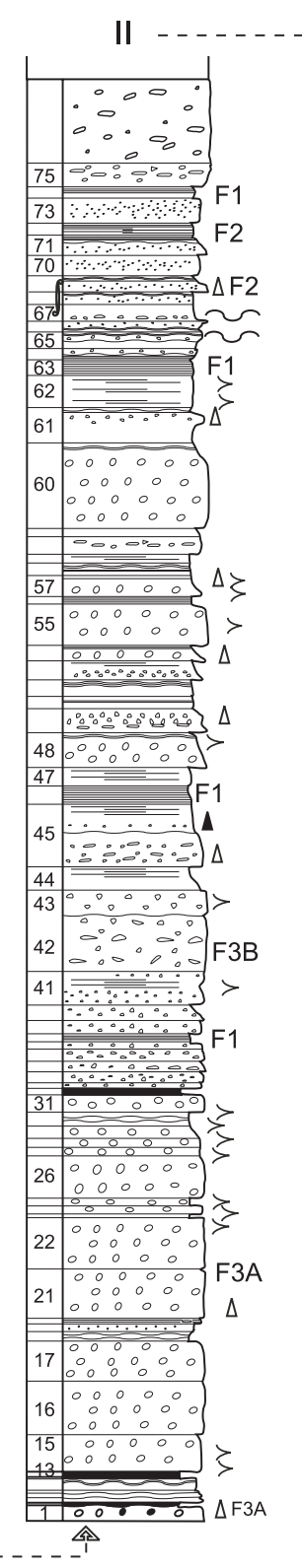

III

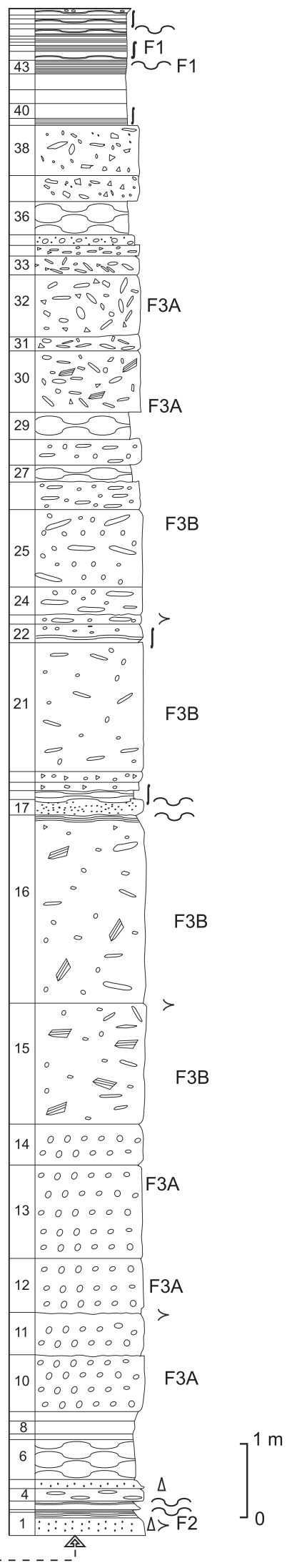


part of Section III. Crinoids abound only in the top part of Section III.

\section{Facies F1: laminated calcisiltites}

Facies F1 consists of thin- to medium-bedded $(2-29 \mathrm{~cm})$, dark-grey micritic limestones with horizontal lamination. They show lowangle cross-lamination and locally hummocky cross-stratification (HCS), especially in the upper part of Section II and in Section III (see Fig. 3). The bottom and top surfaces vary in appearance (Fig. 4A): some are distinct, smooth and planar, whereas upper surfaces can also undulate, whereas the bottom surfaces may be erosional. Rarely, micritic limestones are amalgamated with coarse-grained layers; in these cases top surfaces of the micritic limestones are indistinct.

The lamination is the result of the alternation of thin (approx. 1-4 mm) layers of micrite and pelsparite (Fig. 4B). Mud peloids and aggregate grains (approx. 50\%) occur in the sparite partings. Complete and fragmented fossils are represented by brachiopod shells (up to 0.8424 $\mathrm{mm}$ in length), spherical and elongated calcispheres $(0.058-0.117 \mathrm{~mm}$ ), styliolinids (up to 0.5 $\mathrm{mm}$ ) and rare tubiforms (up to $0.351 \mathrm{~mm}$ ). Styliolinids are frequent mainly in the upper part of the Szydłówek Beds (Section I: the Styliolina Horizon of Pisarzowska et al., 2006, and their fig. 10). In the upper part of the Kostomłoty Beds (Section III), the F1 sediment is occasionally slightly bioturbated (Fig. 4).

\section{Facies F2: fine-grained calcarenites}

The layers of lithofacies F2 are thin- to medium-bedded $(3-17 \mathrm{~cm})$ and consist of grey calcarenites with erosional bases and undulating tops. The bases are sharp and vary in character, from flat to gently wavy to distinctly u-shaped depressions (scours). Small (up to 2 $\mathrm{mm}$ ) micritic clasts fill the depressions and lie on the erosional surfaces. In some cases, the bases are smooth and planar. The calcarenites are graded. The tops of these layers may show horizontal and wavy-lamination and, in a few cases, HCS (Fig. 5).

In thin section, the calcarenites are moderately sorted. The grading is due to a gradual reduction in the proportion of both allochem and orthochem components towards the top. The top part of the layers is characterized by
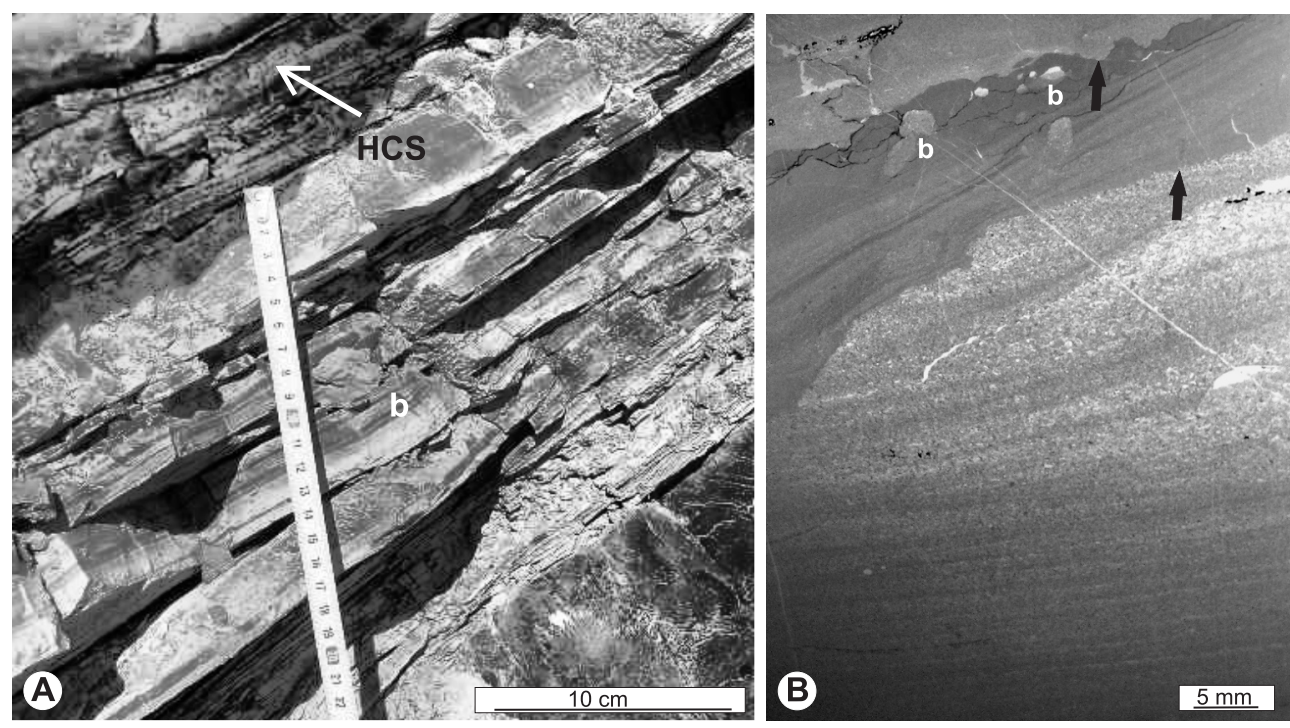

Fig. 4. Facies F1.

A - Field appearance of the laminated calcisiltites layers 42-49, Section III with bioturbated lamination (b) and hummocky cross-stratification (HCS, arrow); B - Thin section (KIII/3) of a calcisiltite from Section III, with lamination reflecting thin alternations of micrite and pelsparite. The horizontal lamination changes into wavy lamination. Note the erosional bases (arrows) and the burrows (b). 

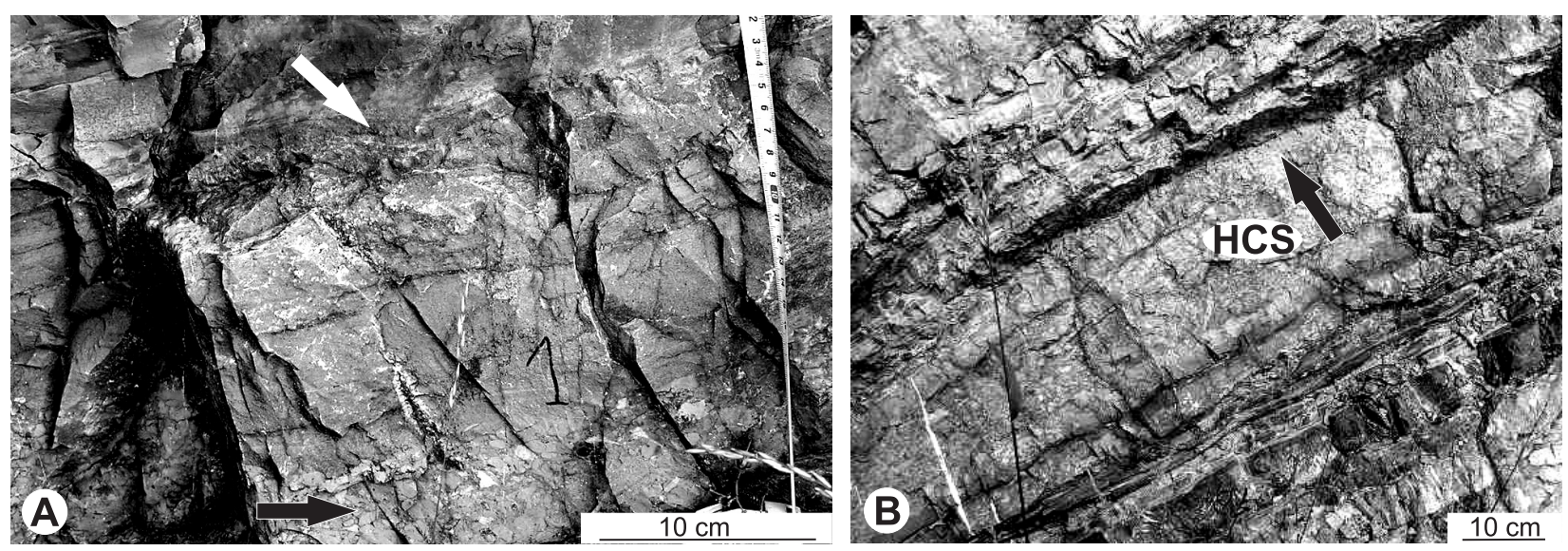

Fig. 5. Facies F2.

A - Graded calcarenite (layer 1, Section III) with numerous small, micritic intraclasts in its lowermost part (black arrow). Wavy laminae are present at the top of the graded bed (white arrow); B - Calcarenite (layer 17, Section III) with hummocky cross-stratification at the top (HCS, arrow).

lamination formed by alternating laminae of micrite and pel(bio)sparite or pelsparite and biopelsparite. The matrix is composed of microspar and sparite. The carbonate grains are represented by mud peloids and rare fecal pellets, which may form aggregate grains (approx. $40 \%$ ). Bioclasts include crinoids (common), brachiopods, calcispheres and styliolinids. Some shells and burrows have geopetal infillings, and the sediment in the top parts of some layers is slightly bioturbated. Irregular, often anastomosing (according to Flügel, 2004) (micro)stylolites are numerous. The amplitudes of the microstylolites are about $1-2 \mathrm{~mm}$.

\section{Facies F3: coarse-grained calcirudites}

This facies consists of thin- to very thickbedded (10-325 cm), light-grey calcirudites composed of intraclasts building breccias and conglomerates; the conglomerates contain mainly low-sphericity, flat and tabular pebbles. The lower boundaries of the individual layers are usually erosional, sharp and flat, but in some cases indistinct. Where the upper parts of the layers display horizontal and/or wavy lamination, the upper boundaries are undulating, but more commonly the boundary is indistinct. These calcirudite layers are often amalgamated. Two sub-facies are distinguished: grain-supported calcirudites (F3A) and matrixsupported calcirudites (F3B).
Sub-facies F3A: grain-supported calcirudites

The calcirudites of sub-facies F3A are clastsupported and poorly to moderately sorted carbonate breccias with irregular, subangular intraclasts of up to $60 \mathrm{~mm}$. According to the Krumbein \& Sloss (1963) chart, the clast sphericity is $0.7-0.9$ and their roundness is 0.3 . The clast's packing varies from clast-supported to condensed by pressure solution as evidenced by microstylolites and stylolites. The fitting of the clasts is often high (Fig. 6A-B), and the clasts are usually arranged without any preferential orientation. The size of the clasts tends to increase along with increasing thickness of the individual layers. Some layers are locally normally graded (Fig. 6A).

The intraclasts are characterized by various textures and components; many intraclasts composed of micrite or biomicrite comprise approx. $10-20 \%$ of grains, mainly calcispheroids and styliolinids. Other calcarenite intraclasts contain shallow-water biota, such as crinoids, brachiopods, foraminifers, calcareous algae and calcispheroids. In the upper part of Section III, crinoidal intraclasts also appear. Apart from the intraclasts, small amounts of a biosparite matrix with crinoid and brachiopod fragments are present.

\section{Sub-facies F3B: matrix-supported calcirudites}

The calcirudites of this sub-facies consist of matrix-supported (locally grain-supported) 

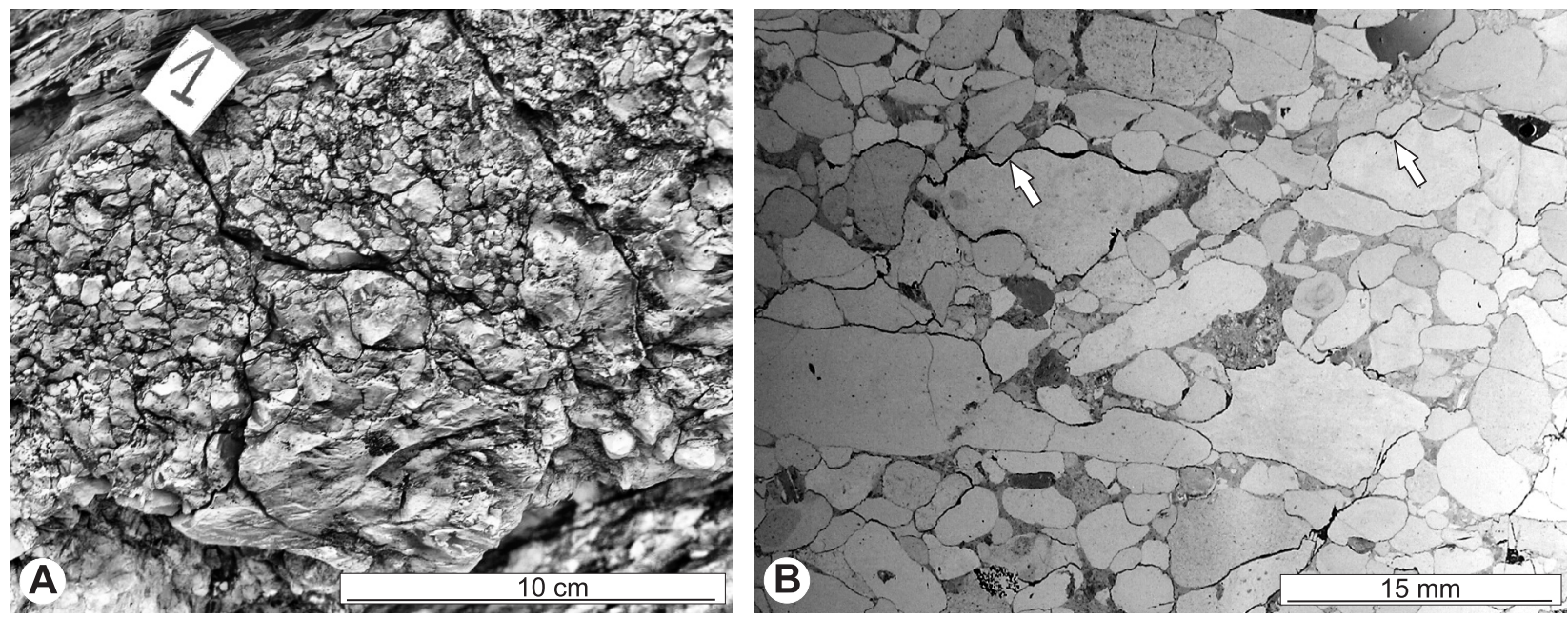

Fig. 6. Sub-facies F3A.

A - Densely packed clast-supported breccia (layer 1, Section II) with a very small amount of matrix showing normal grading and well fitting clasts; B - Thin section (KI/153, Section I) showing a fabric varying from clast-supported to condensed by stylolites (arrow).

and poorly sorted conglomerates with intraclasts of diverse shape, roundness and size (Fig. 7). Locally, the clasts are small (up to several $\mathrm{mm}$ ), spherical and subangular. Elsewhere, they are tabular, highly discoidal, and reaching sizes up to $25 \mathrm{~cm}$ with a thickness of only 1-2 cm. According to the Krumbein \& Sloss (1963) chart, their sphericity is 0.3 and their roundness is $0.5-0.7$. Some intraclasts are broken, cracked or bent. The arranged of the clasts depends on the shape of the pebbles. In thin layers and in the bottom parts of thick layers, the flat pebbles are orientated horizontally or subhorizontally. Thicker layers may contain randomly-oriented, steeply-inclined or even vertically stacked edge-to-edge intraclasts (Fig. 7A). The conglomerates with flat pebbles do not show normal grading, but sporadically reversed grading (e.g. layer 66 in Section I; Fig. 2C). In addition, the flat pebbles in some beds
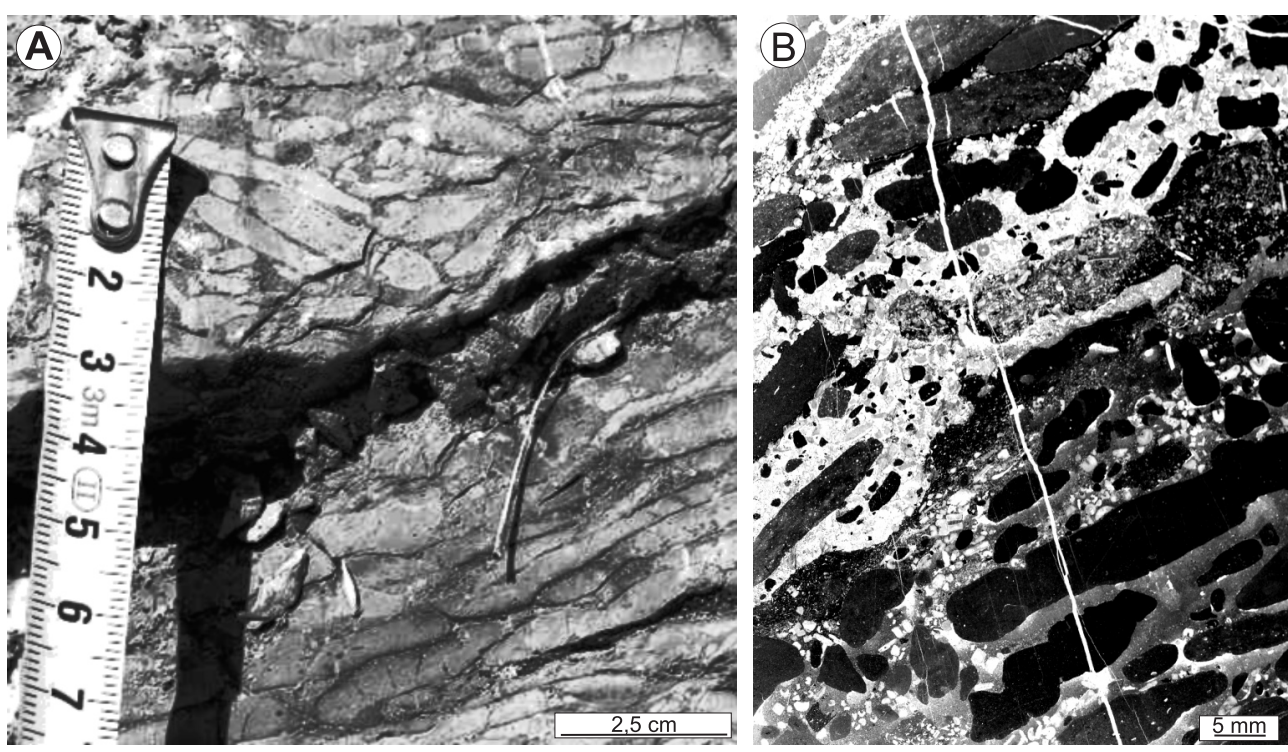

Fig. 7. Sub-facies F3B: flat-pebble conglomerates.

A - Field appearance (layers 32 and 33, Section III) with subhorizontal clasts (lower part of photograph). Edgewise positioned intraclasts are visible at the top; B - Thin section (KIII/34, Section III) showing flat, tabular clasts floating in a microspar and sparite matrix. 

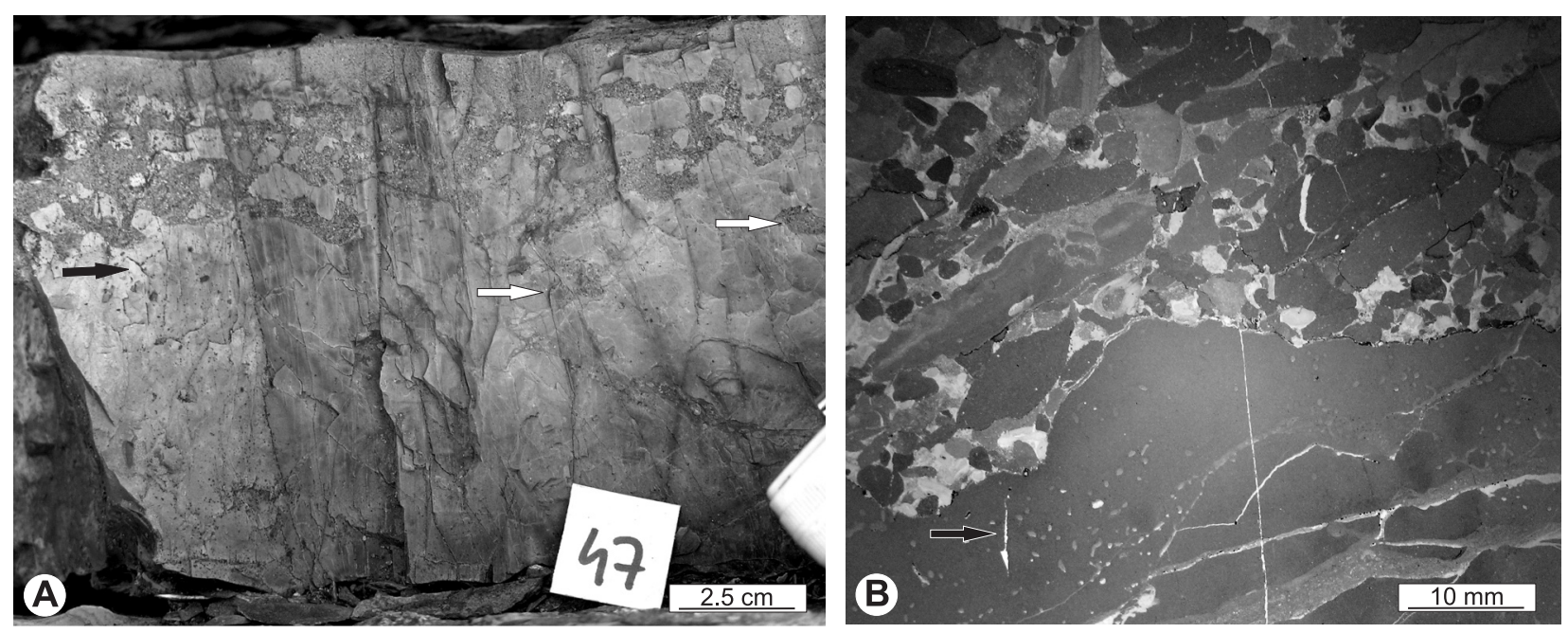

Fig. 8. Sub-facies F3B: calcirudites.

A - Calcirudite (layer 47, Section I) with an erosional surface separating calcirudite and underlying micrite. Note the firmground surface, the distinct burrow in the micrite (white arrow) and Chondrites isp. (black arrow); B - Thin section (KIII/24, Section III) showing small micritic clasts filling a scour. Note Chondrites isp. (arrow).

only occur in the bottom parts of the layers. Occasionally, thick-bedded calcirudites vertically pass into calcarenites and again into calcirudites.

Medium-bedded $(12-20 \mathrm{~cm})$ layers occasionally comprise micrite in their lower part and calcirudite in their upper parts comprising, separated by an erosional surface. Small, micritic intraclasts and bioclasts fill scours. Locally, firmgrounds are present at the top surface of the micritic part. Within the micrite part, ichnofossils (burrow casts) and Chondrites isp. are present (Fig. 8). The horizontal lamination changes into low-angle cross-lamination, and into ?HCS at the top of these beds.
In the middle and upper parts of Section III, large (approx. $5 \mathrm{~cm} \times 20 \mathrm{~cm}$, locally up to $50 \mathrm{~cm}$ in length) angular fragments of, locally distinctly laminated, limestones are embedded in the calcirudites. This lamination is the result of an alternation of calcisiltite and calcarenite. These characteristic intraclasts are few in number and haphazardly arranged (Fig. 9).

The intraclasts have different components and textures. Many intraclasts are composed of micrite and contain up to $10 \%$ of crinoid, brachiopod and calcisphere fragments. Calcarenite intraclasts as described above occur locally. In addition to the intraclasts, mud peloids and fragments of bioclasts are present. These
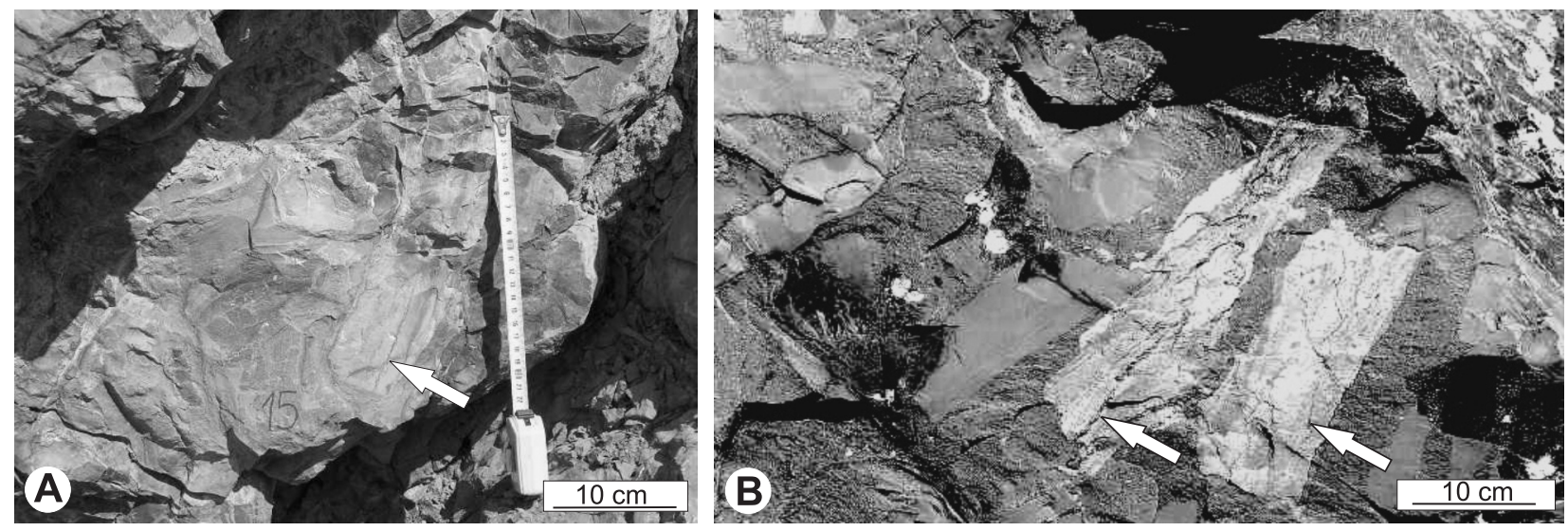

Fig. 9. Haphazardly arranged angular fragments of micritic limestone in calcirudites.

A - Micrite clast with lamination (arrow) in layer 15 (Section III); B - Light-grey tabular and angular micritic clasts (arrowed) in layer 15 (Section III). 
are mainly reef-derived crinoids, brachiopods and corals as well as bryozoans, calcispheres, rare styliolinids and calcareous algae. Geopetal structures and dissolution horizons are occasionally present. The matrix of biosparite is commonly replaced by blocky cement growing around the bioclasts and by pore filling. A micrite matrix occurs only in the uppermost part of Section III. The mutual contacts between the intraclasts can be pointed, tangential or, occasionally, sutured. The matrix-to-intraclast contacts are distinct and locally highlighted by microstylolites.

\section{Discussion}

The Upper Devonian detrital limestones of the HCM were initially interpreted as slumps, mudflow deposits and turbidites (Szulczewski, 1968, 1971). Later, it was suggested that intense storms or even tsunamis had played a role in the deposition of these limestones. Analysis of sections in the Kowala and Wietrznia quarries in the Kielce region (Fig. 1) led to an interpretation as tempestites. Kaźmierczak \& Goldring (1978) described the subtidal flatpebble conglomerate from the Kowala area as a high-energy deposit; the considerable size of the flat pebbles and the complex nature of the matrix were considered as indications of storm or tsunami surges. Several authors thought the flat-pebble conglomerates to have resulted from intense storms (e.g. Sepkoski, 1982; Sepkoski et al., 1991; Myrow et al., 2004). More varied carbonates occur in a transitional facies in the Wietrznia quarry. Intercalations of coarse-grained limestones, including conglomerates and breccias, as well as crinoidal and graded micritic limestones, are frequent there and occur mainly as thin to medium beds. The composition and sedimentary structures of the Wietrznia limestones suggest an origin as proximal-to-distal tempestites (Vierek, 2007b).

The sections of the Kostomłoty Beds are, however, very different from those in the Kowala and Wietrznia quarries. The limestones are coarser and contain more breccias. The intercalations of coarse-grained limestones are less common but the layers are thicker. On the other hand, the laminated calcisiltites and fine-grained calcarenites are similar to the carbonates from the Wietrznia quarry, but in the Kostomłoty Beds they play a decisively smaller, secondary role. This raises the question as to what environment these lithofacies formed in.

According to Racki \& Bultynck (1993) and Racki et al. (2004), the Szydłówek Beds and the Kostomłoty Beds reflect a deeper-water, oxygen-depleted basin setting. However, the appearance of bioturbation in the upper part of the section and fecal pellets in the calcarenites indicate a changing environment and better oxidation of bottom waters (cf. Schieber, 1994; Flügel, 2004). According to Abbassi (2007), trace fossils such as Chondrites reflect moderate to relatively low energy in an intertidal to shallow subtidal zone below the fair-weather wave base, but not below the storm wave base. On the other hand, the micritic texture, the low abundance of bioclasts, and the flat basal and top surfaces of the calcisiltites (in F1) suggest a hemipelagic/pelagic depositional setting below storm wave base, although the laminated intervals, sparite partings and rare erosional bases indicate hydrodynamic reworking by weak bottom currents (maybe due to distal tempestites, see Vierek, 2007b) or deposition by distal turbidity currents (cf. Reineck \& Singh, 1972; Stow \& Bowen, 1978; Bábek et al., 2007). Similarly, the sharp bases, grading, wavy and/or horizontal lamination and HCS (in F2) suggest tempestites (cf. Aigner, 1985; Bábek et al., 2007). The scourand-fill structures observed at the bases must have been created by storm-induced bottom currents or combined flows winnowing the sea floor (cf. Seguret et al., 2001). The geopetal infillings in fossils suggest rapid burial during storm events (Flügel, 2004, p.178). In addition, the fairly large quantity of mud peloids may reflect wave-induced currents that disturbed the bottom sediments (cf. Flügel, 1978, 2004). These peloids may have been reworked from shallower areas. It thus seems that the carbonate sediment was whirled up into suspension, for example by storm waves, and was probably carried offshore into deeper, quieter waters by dilute bottom currents and redeposited at or below the storm wave base. 
Both the coarse-grained nature of the calcirudites and the fragmented and redeposited bioclasts suggest much turbulence and a high energy of the water above the storm wave base, and subsequent transport into the deeper parts of the basin. The large size of the intraclasts (up to $50 \mathrm{~cm}$ ) and the thickness of the calcirudite layers (up to approx. $3 \mathrm{~m}$ ) are also indicative of deposition in a high-energy setting. Transport processes essentially control the formation of calcirudites. The larger the intraclasts, the higher the transport energy can have been. In addition, conglomerates become increasingly well-sorted during transport as bedload, and the proportion of matrix decreases (Flügel, 2004, p. 240). The different degrees of sorting in the sediments described here is probably linked to variations in the depositional conditions and the mechanisms of transport, which factors may also explain the bed morphologies, their variable thicknesses and fabrics. Additionally, the very thick layers, their vertical changes and their low amount or even total lack of mud suggest rare events of extreme magnitude.

The different compositions of the intraclasts suggest that the clasts originated from both erosion of a carbonate-platform margin (micritic and biomicritic intraclast) and from erosion of penecontemporaneous coarse-grained limestones (biocalcarenite and crinoidal intraclasts) building the slope of the platform (cf. Szulczewski et al., 2006). The degree of lithification of the eroded material was variable, as shown by the shapes of the clasts. Sharp contacts between the intraclasts and the matrix indicate that the substratum had become consolidated. The angular laminated clasts were ripped from the consolidated, originally laminated substratum and transported over probably a short distance, as suggested by their size, shape, internal lamination and lack of rounding. Similar blocks and slabs were described by Szulczewski (1968) as slump sheets. Individual intraclasts with both rounded and angular edges suggest breakage during transport. On the other hand, a few slightly rounded and washed intraclasts suggest that a semi-consolidated substratum was eroded.

The classical model (e.g., Aigner, 1985) of storm-induced deposition in a carbonate envi- ronment is therefore impossible, and the depositional history is probably fairly complex. A number of processes must have been involved in generating these carbonate deposits, resulting in a combination of features. These sedimentary features suggest two transport mechanisms: combined flow and gravity flow.

\section{Combined flows}

Strong storm winds produce waves and surface currents. The motion associated with interacting waves and currents is called 'combined flow' (Harms, 1969) and, according to Walker \& Plint (1992), they are unidirectional and oscillatory. Bottom currents interact with orbital wave motion to produce a combined flow of sufficient magnitude that is able, with the proper kinematics, to transport coarse-grained sediments from shoreline sources (Snedden et al., 1988). Mount \& Kidder (1993) suggested that the unusually thick, coarse-grained, edgewise (i.e. sub-vertically oriented) intraclast conglomerate from the Sellick Hill Formation (South Australia) was formed by exceptionally intense, storm-generated combined flows. The intraclasts that they described are, as in the sediments described in the present contribution, tabular with well-rounded to angular edges. In the thinner beds, the intraclasts are lying (sub)horizontally, whereas the thicker beds show vertically-stacked, edgewise intraclasts. Futterer (1982) suggested that edgewise clast orientations are a feature of deposition from powerful oscillatory currents. According to Mount \& Kidder (1993), the edgewise fabric is a product of intraclast acceleration and deceleration during the passage of waves and of the chaotic collisions between intraclasts moving within the layer. In some of the conglomerates in the Kostomłoty-Mogiłki quarry, intraclasts are chaotically oriented. This was, most likely, caused by rapid increases and decreases in bed shear stresses and associated flow competences during the offshore strokes of orbital motion (see Mount \& Kidder, 1993). Besides the arrangement of intraclasts, the combined flows are also responsible for HCS, horizontal and cross-lamination, which structures are present 
all over the studied lithofacies (cf. Duke, 1990; Walker \& Plint, 1992; Seguret et al., 2001).

Storm-induced transport of sediment is also recorded in the sole marks. The specific scourand-fill structures at the base of several beds could be created by storm events or combined flow winnowing the sea floor (e.g. Seguret et al., 2001). Similarly, initial stages of firmground can be ripped up by storms resulting in the intraclastic limestones (see Fig. 8). On the other hand, neither sharp and flat bases nor a lack of bottom marks excludes storm processes. According to Eberli (1991), a lack of cohesion inhibits the preservation of bottom marks and diagenesis in welding a turbidite (and, in the author's opinion, a tempestite) to the underlying limestone beds, which would obscure bottom marks. In the examined limestones, the subrounded and washed intraclasts suggest weakly consolidated sediments. In addition, the frequent amalgamations obscure the base of the beds.

Thus, the laminated calcisiltites, calcarenites, flat-pebble conglomerates and mediumbedded breccias (with erosional surfaces separating calcirudite from the underlying micrite) may be formed by storm events and combined flows.

\section{Gravity flows}

Storms may trigger gravity flows in several depositional settings (e.g. Myrow \& Southard, 1996; Wignall \& Twitchett, 1999; Myrow et al., 2002). Vierek $(2007 a, b)$ interpreted part of the coarse-grained limestones in the Wietrznia quarry as grain flows initiated by storm activity. In the limestones under study here, the combination of poor sorting, irregular orientation of clasts, planar clast fabrics at the base of the layers, the matrix-supported character, the lack of internal structures and the sharp lower and upper boundaries, i.e. all the features in sub-facies F3B, suggest a debris-flow origin (cf. Middleton \& Hampton, 1976; Lash, 1984; Bełka et al., 1996). In addition, the angular, laminated clasts embedded in the matrix may be interpreted as 'rigid plugs', feature of debris flows. However, the fine-grained, sparite matrix pre- cludes transport by a debris flow. Only in a few layers at the top of Section III does the matrix have sufficient cohesion. On the other hand, the clast-supported fabrics (in F3A), poor sorting, edgewise texture and inverse grading (in F3B) suggest deposition by a grain flow (e.g. Middleton \& Hampton, 1976; Lash, 1984). According to Lowe (1976), true grain-flow deposits should be some $5 \mathrm{~cm}$ thick. Thicker deposits, such us the Kostomłoty-Mogiłki limestones, rather suggest a density-modified grain-flow mechanism. Lowe (1976) described these flows as intermediate between true grain flows and debris flows, with the main variable being the amount of mud present. In the KostomłotyMogiłki quarry, features such as an edgewise texture, poor sorting, bioclastic matrix and rare inverse grading may suggest such densitymodified grain flows.

Szulczewski $(1968,1971)$ associated the detrital limestones of the HCM with, among other types, turbidity currents. In fact, thick-bedded, massive and/ or normally graded, coarse-detrital carbonates with crinoids, peloids and abundant intraclasts have been interpreted as highdensity turbidity current deposits (see Fig. 5A; Lowe, 1982; Eder et al., 1983; Kalvoda et al., 1999; Einsele, 2000). Turbidity currents may be triggered by various features. For example, Myrow et al. (2002) described wave-modified turbidity currents associated with storm waves. Such as interpretation is consistent with earlier suggestions concerning storm occurrences and the interpretation of the resulting lithofacies.

The sedimentary features of the examined carbonates do, however, not unequivocally identify a particular mechanism of transport. For example, amalgamation is a feature of turbidites and debris-flow deposits (Einsele, 1991). But first of all, amalgamation and cannibalism are typical features of proximal tempestites (Einsele, 2000, p. 102), in which the great thickness of the coarse-grained layers and the lack of finer sediments reflect advanced cannibalism by tempestites. Therefore, amalgamation scours within some layers and the occurrence of intraclasts with both rounded and angular edges suggests that complex flows may have been involved in the generation of some intraclast-rich horizons (see Mount \& Kidder, 1993). 
Many examples of coarse-grained sediments originating from multiple flows exist. Crevello \& Schlager (1980) believe that poorly-graded beds may be deposited by flows transitional between high-density turbidity currents and debris flows with clast-supporting matrix. Lowe $(1976,1982)$ suggests that density-modified grain-flows may tend to evolve towards high-density turbidity currents. Chen et al. (2001) interpret conglomerates as deposited by debris flows, possibly followed by highdensity turbidity flows. Einsele (2000, p. 214) claims that turbidity currents can evolve from high-density gravity mass flows by taking up additional seawater.

To sum up, such a complex mechanism of transport suggests various factors which caused reworking of the sediment. What, besides storm waves, could have led to reworking of the carbonates exposed in the KostomłotyMogiłki quarry? Two additional factors are possible: (1) a seismic shock and a fluctuating sea level, and (2) slope instability by ongoing sediment accumulation.

The coarse-grained beds at KostomłotyMogiłki are undoubtedly more massive and thicker than the storm beds at Wietrznia. Additionally, the large amount of products of cannibalistic erosion on the slope of the platform in the reworked sediments suggest that the mechanisms were storms and/or seismic activity that could have disturbed the stability of the platform flank, and that might generate tsunamis. Co-occurrence of tempestites, seismites and tsunamites related to platforms is possible (e.g. Pratt, 2002). The clast-supported breccias with a high fitting of intraclasts (in F3A, see Fig. 6) may be interpreted as a hydraulic breccia (see Flügel, 2004, p. 234) near the depositional surface and related to synsedimentary tectonics. Spalletta \& Vai (1984) described very similar Upper Devonian intraclast parabreccias interpreted as seismites. One of the features of seismites (e.g. Nakajiama \& Kanai, 2000) can be the common occurrence of amalgamations, as described here (see Fig. 3). Similarly, as described by Myrow et al. (2004), the flat-pebble conglomerate (F3B, see Fig. 7) may have resulted from a seismic shock (cf. Kaźmierczak \& Goldring, 1978). In addition, tectonic deforma- tions in the upper part of the Szydłówek Beds and the lowermost part of the Kostomłoty Beds in the Kostomłoty-Mogiłki quarry support an interpretation as seismites, as does the history of Late Devonian tectonics in the HCM (Racki \& Narkiewicz, 2000; Skompski \& Szulczewski, 2000; Lamarche et al., 2003). According to Pisarzowska et al. (2006), tectonic effects of the Frasnian age are particularly well developed at the northern slope of the Dyminy Reef, exposed in Kielce Region, ca. 10 kilometres SSE of Kostomłoty site.

Playford et al. (1989) believe that the evolution and morphology of the Devonian carbonate platforms in the Canning Basin (West Australia) during the Middle-Late Devonian were controlled by variations in the rates of relative sea-level change due to eustasy and tectonism. Johnson et al. (1985) attributed several worldwide transgressive/regressive cycles during the Devonian to eustatic sea-level fluctuations. According to Eberli (1991), sea-level fluctuations commonly influence sediment production. During sea-level lowstands, storm or tsunami surges may lead to channeling and coarse-grained limestone deposition. Channels may have cut the margin of the Upper Devonian carbonate platform, and perhaps the Kostomłoty Beds were situated at their outlets. In the lower part of the Kostomłoty Beds, the lithofacies are arranged into small-scale, coarsening-upward cycles, and this cyclicity shows sea-level fluctuations and a few deepening episodes (Vierek, 2010). The first deepening episode was marked in the late $P a$. transitans Zone and corresponds to the Timan global events (sensu Becker \& House, 1997). The next deepening pulse took place during the middle of the Pa. punctata Zone. Between the deepening pulses, shallowing-upward phases occurred. Local tectonics and episodic subsidence played a significant role in cyclic developments. It seems that the shallowing, mentioned earlier by Racki \& Narkiewicz (2000), is not a local occurrence: sedimentological and stratigraphic analyses in South China also provide evidence for a sea-level fall during the latest Frasnian (Chen \& Tucker, 2003).

Finally, the Upper Devonian carbonate platform in the HCM is a reef-rimmed isolated 
platform with a steep margin (Szulczewski, 1995; Vierek, 2007b). The steep margin of the platform will have facilitated the development of gravity flows and offshore transport, often to depths of over $50 \mathrm{~m}$, which is too deep to be reworked and transported by storm waves (Nott, 2006, p. 86). An increased slope angle increases the shear stress within the sediment (Spence \& Tucker, 1997). Overloading and/or oversteepening can lead to gravitational instability on previously stable slopes, culminating in collapse, large-scale slumps, debris flows and turbidity currents (e.g. Einsele, 1991).

\section{Conclusions}

The following conclusions can be drawn:

(1) The Kostomłoty Beds in the KostomłotyMogiłki quarry are composed of shales, micritic and nodular limestones with intercalations of laminated and coarse-grained limestones of variable grain size. The shales, micritic and nodular limestones record background sedimentation. The laminated and coarse-grained limestones represent event beds.

(2) Three depositional lithofacies are distinguished on the basis of grain size, composition, texture and sedimentary structures: laminated calcisiltites (F1), fine-grained calcarenites (F2), coarse-grained calcirudites, which are subdivided into grain-supported calcirudites (F3A) and matrix-supported calcirudites (F3B).

(3) Intraclasts composed of calcirudites originate from both erosion of an older carbonate-platform margin and erosion of penecontemporaneous coarse-grained limestones building the slope of the platform.

(4) The laminated calcisiltites (F1), calcarenites (F2) and part of the calcirudites, i.e. the medium-bedded breccias with erosional surfaces separating calcirudite from the underlying micrite, were formed by storm activity and combined flows.

(5) The thick grain-supported breccias (F3A) and the flat-pebble conglomerates (F3B) are interpreted as seismites and related to synsedimentary tectonics.

(6) Storms and tectonic activity affecting the stability of the slope were the main causes of erosion in the study area. Combined and gravity flows were the transporting mechanism involved in the reworking and redeposition of the carbonate material.

\section{Acknowledgements}

My grateful thanks are due to Dr Beatriz Bádenas and Prof. Joachim Szulc for their constructive critical reading and their comments, which have helped greatly to improve this contribution. My thanks are also due to M. Manowska for help with the drawings.

\section{References}

Abbassi, N., 2007. Shallow marine trace fossils from Upper Devonian sediments of the Kuh-E Zard, Zefreh area, Central Iran. Iranian Journal of Science \& Technology 31, A1, 23-33.

Aigner, T., 1985. Storm depositional systems: dynamic stratigraphy in modern and ancient shallow-marine sequences. Lecture Notes in Earth Sciences (Springer-Verlag, Berlin) 3, 174 pp.

Bábek, O., Přikryl, T. \& Hladil, J., 2007. Progressive drowning of carbonate platform in the Moravo-Silesian Basin (Czech Republic) before the Frasnian/Famennian event: facies, compositional variations and gamma-ray spectrometry. Facies 53, 293-316.

Becker, T.T. \& House, M.R., 1997. Sea level changes in the Upper Devonian of the Canning Basin, Western Australia. Courier Forschungsinstitut Senckenberg 199, 129-146.

Bełka, Z., Skompski, S. \& Soboń-Podgórska, J., 1996. Reconstruction of a lost carbonate platform on the shelf of Fennosarmatia: evidence from Visėan polymictic debrites, Holy Cross Mountains, Poland. Geological Society, London, Special Publication 107, 315-329.

Chen, D. \& Tucker, M.E., 2003. The Frasnian-Famennian mass extinction: insights from high-resolution sequence stratigraphy and cyclostratigraphy in South China. Palaeogeography Palaeoclimatology Palaeoecology 193, 87-111.

Chen, D., Tucker, M.E., Jiang, M. \& Zhu, J., 2001. Longdistance correlation between tectonic-controlled, isolated carbonate platforms by cyclostratigraphy and sequence stratigraphy in the Devonian of South China. Sedimentology $48,57-78$.

Crevello, P.D. \& Schlager, W., 1980. Carbonate debris sheets and turbidites, Exuma Sound, Bahamas. Journal of Sedimentary Petrology 50, 1121-1148.

Duke, W.L., 1990. Geostrophic circulation or shallow marine turbidity currents? The dilemma of paleo-flow patterns in storm-influenced prograding shoreline systems. Journal of Sedimentary Petrology 60, 870-883. 
Eberli, G.P., 1991. Calcareous turbidites and their relationship to sea-level fluctuations and tectonism. [In:] G. Einsele, W. Ricken \& A. Seilacher (Eds): Cycles and events in stratigraphy. Springer, Berlin, 340-359.

Eder, F.W., Engel, W., Franke, W. \& Sadler, P.M., 1983. Devonian and Carboniferous limestone-turbidites of the Rheinisches Schiefergebirge and their tectonic significance [In:] H. Martin \& F.W. Eder (Eds): Intracontinental fold belts. Springer-Verlag, Berlin, 93-124.

Einsele, G., 1991. Submarine mass flow deposits and turbidites. [In:] G. Einsele, W. Ricken \& A. Seilacher (Eds): Cycles and events in stratigraphy. Springer, Berlin, 313-339.

Einsele, G., 2000. Sedimentary basins: evolution, facies and sediment budget. Springer, Berlin, $792 \mathrm{pp}$.

Flügel, E., 1978. Mikrofazielle Untersuchungsmethoden von Kalken. Springer, 454 pp.

Flügel, E., 2004. Microfacies of carbonate rocks. Analysis, interpretation and application. Springer, Berlin, 976 pp.

Folk, R.L., 1959. Practical petrographical classification of limestones. American Association of Petroleum Geologists Bulletin 43, 1-38.

Folk, R.L., 1962. Spectral subdivision of limestone types. American Association of Petroleum Geologists Memoirs 1, 62-84.

Futterer, E., 1982. Experiments on the distinction of wave and current influenced shell accumulations. [In:] G. Einsele \& A. Seilacher (Eds): Cyclic and event stratification. Springer, Berlin, 174-179.

Harms, J.C., 1969. Hydraulic significance of some sand ripples. Geological Society of American Bulletin 80, 363396.

Johnson, J.G., Klapper, G., Sandberg, C.A., 1985. Devonian eustatic fluctuations in Euramerica. Geological Society of American Bulletin 96, 567-587.

Kalvoda, J., Bábek, O. \& Malovaná, A., 1999. Sedimentary and biofacies records in calciturbidites at the Devonian-Carboniferous boundary in Moravia (MoravianSilesian Zone, Middle Europe). Facies 41, 141-158.

Kaźmierczak, J. \& Goldring, R., 1978. Subtidal flat-pebble conglomerate from the Upper Devonian of Poland: a multiprovenant high-energy product. Geological Magazine 115, 359-366.

Krumbein, W.C. \& Sloss, L.L., 1963. Stratigraphy and sedimentation $\left(2^{\text {nd }} \mathrm{ed}\right)$. Freeman and Company, San Francisco, $660 \mathrm{pp}$.

Lamarche, J., Lewandowski, M., Mansy, J.L. \& Szulczewski, M., 2003. Partitioning pre-, syn- and post-Variscan deformation in the Holy Cross Mts., eastern Variscan foreland. [In:] T. McCann \& A. Saintot (Eds): Tracing tectonic deformation using the sedimentary record. Geological Society, London, Special Publication 208, 159-184.

Lash, G.G., 1984. Density-modified grain-flow deposits from an Early Paleozoic passive margin. Journal of Sedimentary Petrology 54, 557-562.

Lowe, D.R., 1976. Grain flow and grain flow deposits. Journal of Sedimentary Petrology 46, 188-199.

Lowe, D.R., 1982. Sediment gravity flows: II. Depositional models with special reference to the deposits of high- density turbidity currents. Journal of Sedimentary Petrology 52, 279-297.

Middleton, G.V. \& Hampton, M.A., 1976. Subaqueous sediment transport and deposition by sediment gravity flows. [In:] D.J. Stanley \& D.J. Swift (Eds): Marine sediment transport and environmental management. John Wiley and Sons, New York, 197-218.

Mount, J.F. \& Kidder, D., 1993. Combined flow origin of edgewise intraclast conglomerates: Sellick Hill Formation (Lower Cambrian), South Australia. Sedimentology 40, 315-329.

Myrow, P.M. \& Southard, J.B., 1996. Tempestite deposition. Journal of Sedimentary Research 66, 875-887.

Myrow, P.M., Fischer, W. \& Goodge, J.W., 2002. Wavemodified turbidites: combined-flow shoreline and shelf deposits, Cambrian, Antarctica. Journal of Sedimentary Research 72, 641-656.

Myrow, P.M., Tice, L., Archuleta, B., Clark, B., Taylor, J.F. \& Ripperdan, R.L., 2004. Flat-pebble conglomerate: its multiple origins and relationship to metre-scale depositional cycles. Sedimentology 51, 973-996.

Nakajiama, T. \& Kanai, Y., 2000. Sedimentary features of seismoturbidites triggered by the 1983 and older historical earthquakes in the eastern margin of the Japan Sea. Sedimentary Geology 135, 1-19.

Narkiewicz, M., 1988. Turning points in sedimentary development in the Late Devonian in southern Poland. [In:] N.J. McMillan, A.F. Embry \& D.J. Glass (Eds): Devonian of the world. Canadian Society of Petroleum Geologists Memoirs 14, 610-635.

Nott, J., 2006. Extreme events - a physical reconstruction and risk assessment. Cambridge University Press, 297 pp.

Pisarzowska, A., Sobstel, M. \& Racki, G., 2006. Conodontbased event stratigraphy of the Early-Middle Frasnian transition on the South Polish carbonate shelf. Acta Palaeontologica Polonica 51, 609-646.

Playford, P.E., Hurley, N.F., Kerans, C. \& Middleton, M.F., 1989. Reefal platform development, Devonian of the Canning Basin, Western Australia. [In:] P.D. Crevello, J.L. Wilson, J.F. Sarg \& J.F. Read (Eds): Controls on carbonate platform and basin development. SEPM Special Publication 44, 187-202.

Pratt, B.R., 2002. Storms versus tsunamis: dynamic interplay of sedimentary, diagenetic, and tectonic processes in the Cambrian of Montana. Geology 30, 423-426.

Racki, G., 1993. Evolution of the bank to reef complex in the Devonian of the Holy Cross Mountains. Acta Palaeontologica Polonica 37, 87-182.

Racki, G. \& Bultynck, P., 1993. Conodont biostratigraphy of the Middle to Upper Devonian boundary beds in the Kielce area of the Holy Cross Mts. Acta Geologica Polonica 43, 1-25.

Racki, G. \& Narkiewicz, M., 2000. Tektoniczne a eustatyczne uwarunkowania rozwoju sedymentacji dewonu świętokrzyskiego [Tectonic versus eustatic controls of sedimentary development of the Devonian in the Holy Cross Mts., central Poland]. Przeglad Geologiczny $48,65-76$.

Racki, G., Głuchowski, E. \& Malec, J., 1985. The Givetian and Frasnian succession at Kostomłoty in the Holy 
Cross Mts., and its regional significance. Bulletin of the Polish Academy of Sciences, Earth Sciences 33, 159-171.

Racki, G., Piechota, A., Bond, D. \& Wignall, P., 2004. Geochemical and ecological aspects of lower Frasnian pyrite-ammonoid level at Kostomłoty (Holy Cross Mts., Poland). Geological Quarterly 48, 267-282.

Reineck, H.E. \& Singh, I.B., 1972. Genesis of laminated sand and graded rhythmites in storm-sand layers of shelf mud. Sedimentology 18, 123-128.

Schieber, J., 1994. Evidence for high-energy events and shallow-water deposition in the Chattanooga Shale, Devonian, central Tennessee, USA. Sedimentary Geology 93, 193-208.

Seguret, M., Moussine-Pouchkine, A., Gabaglia, G.R. \& Bouchette, F., 2001. Storm deposits and storm-generated coarse carbonate breccias on a pelagic outer shelf (South-East Basin, France). Sedimentology 48, 231-254.

Sepkoski, Jr., J.J., 1982. Flat-pebble conglomerates, storm deposits, and the Cambrian bottom fauna. [In:] G. Einsele \& A. Seilacher (Eds): Cyclic and event stratification. Springer-Verlag, Berlin, 371-385.

Sepkoski, Jr., J.J., Bambach, R.K. \& Droser, M.L., 1991. Secular changes in Phanerozoic event bedding and the biological overprint. [In:] G. Einsele, W. Ricken \& A. Seilacher (Eds): Cycles and events in stratigraphy. Springer-Verlag, Berlin, 298-312.

Skompski, S. \& Szulczewski, M., 2000. Lofer-type cyclothems in the Upper Devonian of the Holy Cross Mts. (central Poland). Acta Geologica Polonica 50, 393406.

Snedden, J.W., Nummedal, D. \& Amos, A.F., 1988. Stormand fair-weather combined flow on the central Texas continental shelf. Journal of Sedimentary Petrology 58, 580-595.

Spalletta, C \& Vai, G.B., 1984. Upper Devonian intraclast parabreccias interpreted as seismites. Marine Geology 55, 133-144.

Spence, G.H. \& Tucker, M.E., 1997. Genesis of limestone megabreccias and their significance in carbonate sequence stratigraphic models: a review. Sedimentary Geology 112, 163-193.

Stow, D.A.V. \& Bowen, A.J., 1978. Origin of lamination in deep sea, fine-grained sediments. Nature 274, 324328.

Szulczewski, M., 1968. Slump structures and turbidites in Upper Devonian limestones of the Holy Cross Mts. Acta Geologica Polonica 18, 304-326.

Szulczewski, M., 1971. Upper Devonian conodonts, stratigraphy and facial development in the Holy Cross Mts. Acta Geologica Polonica 21, 1-129.
Szulczewski, M., 1977. Główne regiony facjalne w Paleozoiku Gór Świętokrzyskich [Main facial regions in the Paleozoic of Holy Cross Mts.]. Przegląd Geologiczny 25, 428-432.

Szulczewski, M., 1981. Dewon środkowy i górny zachodniej części Gór Świętokrzyskich [Middle and Upper Devonian in the western part of the Holy Cross Mts.]. Przewodnik 53 Zjazdu PTG, Kielce, 68-82.

Szulczewski, M., 1995. Depositional evolution of the Holy Cross Mts. (Poland) in the Devonian and Carboniferous - a review. Geological Quarterly 39, 471-488.

Szulczewski, M., Bełka, Z. \& Skompski, S., 1996. The drowing of a carbonate platform: an example from the Devonian-Carboniferous of the southwestern Holy Cross Mountains, Poland. Sedimentary Geology 106, 21-49.

Szulczewski, M., Konon, A., Narkiewicz, M., Skompski, S. \& Wańkiewicz, A., 2006. Dewon zachodniej części Gór Świętokrzyskich (Bukowa Góra - Mogiłki - Wietrznia - Ostrówka) [Devonian in the western part of the Holy Cross Mts. (Bukowa Mts. - Mogiłki - Wietrznia - Ostrówka)]. LXXVII Zjazd Polskiego Towarzystwa Geologicznego, Kielce, 19 pp.

Vierek, A., 2007a. Transitional reef-to-basin facies of Lower Frasnian limestones determined by microfacies analysis (Wietrznia, Holy Cross Mts., Poland). Facies 53, 141-155.

Vierek, A., 2007b. Storm-dominated deposition on a Frasnian carbonate platform margin (Wietrznia, Holy Cross Mts., Poland). Geological Quarterly 51, 307-318.

Vierek, A., 2010. Małoskalowa cykliczna sedymentacja we franie Gór Świętokrzyskich [Small-scale cyclic sedimentation in the Frasnian of the Holy Cross Mts.]. Materiaty konferencyjne IV Polskiej Konferencji Sedymentologicznej, POKOS4, p.103.

Walker, R.G. \& Plint, A.G., 1992. Wave- and storm-dominated shallow marine systems. [In:] R.G. Walker \& N.P. James (Eds): Facies models response to sea level change. Geological Association of Canada, 219-238.

Wignall, P.B. \& Twitchett, R.J., 1999. Unusual intraclastic limestones in Lower Triassic carbonates and their bearing on the aftermath of the end-Permian mass extinction. Sedimentology 46, 303-316.

Ziegler, W. \& Sandberg, A.S., 1990. The Late Devonian standard conodont zonation. Courier Forschungsinstitut Senckenberg 121, 1-115. 